\begin{tabular}{|l|l|l||}
\hline \multicolumn{2}{|c|}{ PublisherInfo } \\
\hline \hline PublisherName & $:$ & BioMed Central \\
\hline \hline PublisherLocation & $:$ & London \\
\hline \hline PublisherImprintName & $:$ & BioMed Central \\
\hline \hline
\end{tabular}

\title{
Balancing act
}

\begin{tabular}{|l|l|l||}
\hline \multicolumn{2}{|c||}{ ArticleInfo } \\
\hline \hline ArticleID & $:$ & 4838 \\
\hline \hline ArticleDOI & $:$ & 10.1186 /gb-spotlight-20030904-01 \\
\hline \hline ArticleCitationID & $:$ & spotlight-20030904-01 \\
\hline \hline ArticleSequenceNumber & $:$ & 190 \\
\hline \hline ArticleCategory & $:$ & Research news \\
\hline ArticleFirstPage & $:$ & 1 \\
\hline \hline ArticleLastPage & $:$ & 3 \\
\hline \hline & & RegistrationDate : 2003-9-4 \\
\hline ArticleHistory & $:$ & OnlineDate \\
\hline \hline ArticleCopyright & $:$ & BioMed Central Ltd2003-4 \\
\hline \hline ArticleGrants & $:$ & \\
\hline \hline ArticleContext & $:$ & 130594411 \\
\hline \hline
\end{tabular}




\section{Cathy Holding}

Email: cholding@hgmp.mrc.ac.uk

Comparison of primary DNA sequences between closely related organisms is a powerful tool for identifying important, conserved genetic sequences, and the function of unknown sequences may be inferred from protein motifs and degrees of relatedness to other members of the same family. Another approach to the functional dissection of a genome is to induce mutations in genes and observe their effects on development and fertility. In the September 4 Nature, Benjamin Kile and colleagues at the Baylor College of Medicine - whose laboratory originally engineered a balancer chromosome - show how balancer chromosomes can be utilized in mice for the purposes of maintaining the integrity of lethal mutant stocks and for use as a crucial tool in mutagenesis screening (Nature 2003, 425:81-86).

Kile et al. performed a series of three-generation breeding schemes to assess the effects of mutating genes on mouse chromosome 11, which has conserved linkage to a gene-rich segment of human chromosome 17 that includes the breast cancer gene Brcal and the developmentally crucial Hoxbgenes. The balancer genetic screen was designed to isolate all lethal mutations from fertilization through to adulthood. They found many mutations to be lethal when homozygous, with different phenotypes at various developmental stages, that included neural tube defects and defects in organs and tissues, effects on growth and skeletal morphology, craniofacial development, fertility, and reproduction, as well as blood cell abnormalities and neurological defects. In addition to the discovery of 230 new recessive mutations - 88 of which are on chromosome 11 - the authors constructed several potential murine models of human genetic diseases and revealed a previously unidentified gene involved in cardiac development.

"New mouse mutations are the key to functional genomic studies that will unravel mammalian systems biology. Genome sequencing shows that the mammalian genome contains fewer genes than previously predicted. However, transcriptome and proteome analysis suggests that higher organism complexity is produced not by an increase in the absolute number of genes but by changes in temporal and spatial transcript expression as well as alternate transcript and protein isoform production," the authors conclude.

\section{References}

1. Nature, [http://www.nature.com/nature]

2. Department of Molecular and Human Genetics, Baylor College of Medicine, [http://www.bcm.tmc.edu/departments/genetics.html]

3. Engineering a mouse balancer chromosome

This PDF file was created after publication. 